\title{
A novel resveratrol analogue, HS-1793, inhibits hypoxia-induced HIF-1 $\alpha$ and VEGF expression, and migration in human prostate cancer cells
}

\author{
DONG HWAN KIM ${ }^{1}$, MOHAMMAD AKBAR HOSSAIN ${ }^{1,2}$, MIN YOUNG KIM ${ }^{1}$, JIN-AH KIM ${ }^{1}$, \\ JEONG-HYUN YOON ${ }^{1}$, HONG SUK SUH ${ }^{3}$, GI-YOUNG KIM ${ }^{4}$, YUNG HYUN CHOI ${ }^{5}$, \\ HAE YOUNG CHUNG ${ }^{1}$ and NAM DEUK KIM ${ }^{1}$
}

\footnotetext{
${ }^{1}$ Department of Pharmacy, Molecular Inflammation Research Center for Aging Intervention, Pusan National University, Busan 609-735, Republic of Korea; ${ }^{2}$ Department of Pharmacology and Toxicology, Faculty of Pharmacy, Umm Al-Qura University, Makkah, Kingdom of Saudi Arabia; ${ }^{3}$ Department of Chemistry and Chemistry Institute for Functional Materials, Pusan National University, Busan 609-735;

${ }^{4}$ Faculty of Applied Marine Science, Cheju National University, Jeju 690-756;

${ }^{5}$ Department of Biochemistry, Dongeui University College of Oriental Medicine, Busan 614-052, Republic of Korea
}

Received July 14, 2013; Accepted September 16, 2013

DOI: 10.3892/ijo.2013.2116

\begin{abstract}
In many studies, resveratrol has been shown to have a chemopreventive effect in various types of cancer cells. However, the biological activity of resveratrol is limited by its photosensitivity and metabolic instability. This study investigated the effects of a novel analogue of resveratrol, HS-1793, on the expression of HIF-1 $\alpha$ and vascular endothelial growth factor (VEGF) in PC-3 human prostate cancer cells. Hypoxic condition induced HIF-1 $\alpha$ protein level in PC-3 cells in a time-dependent manner, and treatment with HS-1793 markedly decreased HIF-1 $\alpha$ expression levels. HS-1793 also inhibited VEGF level. Mechanistically, HS-1793 inhibited HIF-1 $\alpha$ and VEGF expression through multiple mechanisms. Firstly, HS-1793 inhibited phosphorylation of PI3K and Akt in PC-3 cells. Furthermore, HS-1793 substantially induced HIF-1 $\alpha$ protein degradation through the proteasome pathway. Finally, HS-1793 inhibited hypoxia-induced PC-3 cell migration. These data suggest that HS-1793 may inhibit human prostate cancer progression and angiogenesis by inhibiting the expression of HIF-1 $\alpha$ and VEGF. Moreover, HS-1793 showed more potent effects than resveratrol on the cytotoxic effects on PC-3 cells. Taken together, these results implied
\end{abstract}

Correspondence to: Dr Nam Deuk Kim, Department of Pharmacy, College of Pharmacy, Pusan National University, Busan 609-735, Republic of Korea

E-mail: nadkim@pusan.ac.kr

Key words: resveratrol analogue, prostate cancer cells, hypoxiainducible factor-1, vascular endothelial growth factor that HS-1793, a novel analogue of resveratrol, may be a new potent chemopreventive agent against human prostate cancer cells.

\section{Introduction}

Hypoxia is known to be associated with an increased tumor metastasis and poor survival in cancer patients (1). Hypoxia activates angiogenesis and stimulates vascular remodeling through hypoxia-inducible factor-1 (HIF-1) signaling pathway. HIF-1 is a heterodimeric transcription factor composed of HIF-1 $\alpha$ and aryl hydrocarbon receptor nuclear translocator (ARNT, HIF-1 $\beta$ ), and controls the expression of several genes regulated by hypoxia (2). HIF-1 $\alpha$ and HIF-1 $\beta$ mRNAs are constantly expressed under normoxic and hypoxic conditions. However, HIF-1 $\alpha$ protein is significantly increased by hypoxia, whereas the HIF-1 $\beta$ protein remains constant regardless of oxygen tension (3). Under normoxia, HIF- $1 \alpha$ protein is remarkably unstable and its degradation by the proteasome is orchestrated by the ubiquitin protein ligase Von Hippel-Lindeau (VHL). In tumor cells, HIF-1 activates the transcription of genes involved in anaerobic metabolism, angiogenesis, survival, invasion/metastasis, serum deprivation and treatment resistance, thus promoting cellular adaptation and survival under hypoxic conditions (4). In cancer patients, the extent of tumor hypoxia directly correlates with advanced disease stages, poor prognosis and treatment resistance (5). In response to hypoxia, HIF-1 $\alpha$ activates the expression of many downstream genes including vascular endothelial growth factor (VEGF), and thus HIF-1 and VEGF play an important role in angiogenesis and tumor progression. HIF-1 $\alpha$ and VEGF expression are upregulated in prostate cancer cells (6). Because HIF-1 $\alpha$ plays a central role in progression and invasion of tumors and metastasis, 
targeting HIF-1 $\alpha$ using small molecule inhibitors represents an attractive strategy for anticancer therapy and/or chemoprevention of prostate cancer (7).

Prostate cancer ( $\mathrm{PCa})$ is a commonly diagnosed cancer in men, and it is the second leading cause of death in men in European Union (EU) and in the USA. The rate of PCa among all new cancer cases has been estimated at $12 \%$ in the EU and $29 \%$ in the USA (8). Behavior of PCa is mostly unpredictable; however, its relatively slow progression to malignancy and metastasis provides broader possibilities for its managements, including the suitability for chemopreventive intervention using naturally occurring of synthetic agents (9).

Trans-3,4,5'-trihydroxystilbene (resveratrol, Fig. 1A), a polyphenol found in grapes, red wines, peanuts and mulberries, has been reported to exhibit a wide range of biological and pharmacological properties (10). Moreover, resveratrol has been reported to possess the ability to intervene in multistage carcinogenesis. Resveratrol has been shown to induce apoptosis in LNCaP and DU145 prostate cancer cell lines (11). Resveratrol has been reported to inhibit the expression of HIF-1 $\alpha$ and VEGF in OVCAR-3 cells through multiple mechanisms, such as inhibition of Akt and mitogen-activated protein kinase (MAPK), inhibition of protein translation regulators, and enhancement of proteasomal degradation of HIF-1 $\alpha$ protein (12). Moreover, resveratrol significantly reduced hypoxia-induced HIF-1 $\alpha$ protein accumulation and VEGF expression in human tongue squamous cell carcinomas and HepG2 cells, without affecting HIF-1 $\alpha$ mRNA expression, partly by inhibiting activation of extracellular signal-regulated kinases (ERK) and Akt, and promoting proteasomal degradation of HIF-1 $\alpha$ (13). Resveratrol also inhibited lysophosphatidic acid-induced metastasis under hypoxic condition in colon cancer cells (14). However, the underlying mechanism of its anti-angiogenic activity remains unclear. Moreover, the biological activity of resveratrol is limited by its photosensitivity and metabolic instability. In addition, resveratrol is not a potent cytotoxic agent when compared with other chemotherapeutic drugs. Thus, the simplicity of resveratrol, associated with its interesting anticancer activity, offers promise for the rational design of new chemotherapeutic agents.

Several studies reported several resveratrol analogues showing stronger antitumor effects than resveratrol (15). A novel resveratrol analogue, HS-1793 (Fig. 1B), does not contain the unstable double bond which resveratrol has. In addition, the position of two of three hydroxyl groups in HS-1793 at the aromatic ring is different from resveratrol. HS-1793 has been shown to inhibit tyrosinase activity more strongly than resveratrol (16). HS-1793 protects rat heart against hypoxia/reoxygenation injury via attenuating mitochondrial damage (17). HS-1793, compared to resveratrol, exerted more effective apoptosis induction in Akt-activated cells and showed stronger antitumor activity (18). HS-1793 induces apoptosis in human breast cancer cells $(19,20)$ and overcomes the resistance conferred by Bcl-2 in human leukemic U937 cells (21). HS-1793 enhances antitumor immunity by reducing the $\mathrm{CD} 4{ }^{+} \mathrm{CD} 25^{+}$regulatory $\mathrm{T}$ cells in FM3A tumor bearing mice (22) and induces the modulation of tumor-derived T cells (23). Moreover, HS-1793 exhibits potent inhibition of the viability of LNCaP human prostate cancer cells (24).

In this study, we used resveratrol and HS-1793 to investigate and compare their effects on the expression of HIF- $1 \alpha$ and
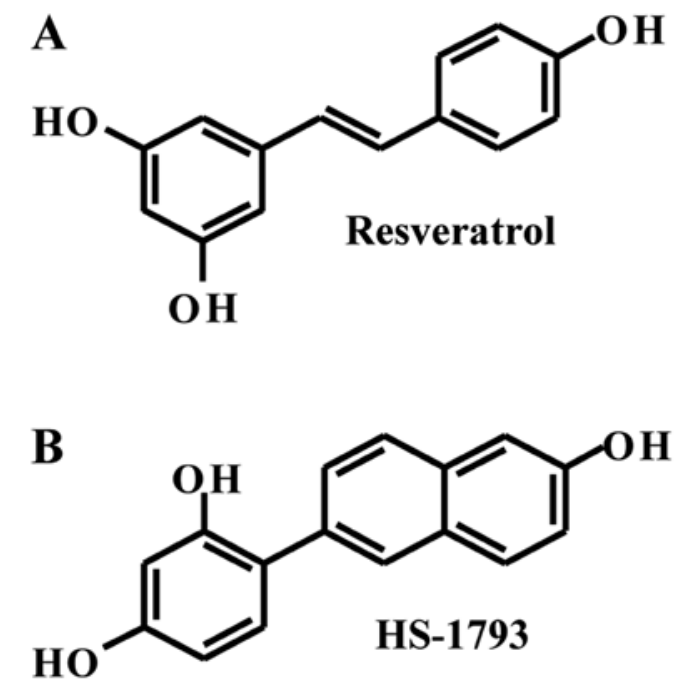

Figure 1. Chemical structures of (A) resveratrol and (B) HS-1793.

VEGF, and migration under hypoxic condition in PC-3 human prostate cancer cells.

\section{Materials and methods}

Chemicals. Trans-3,4,5'-trihydroxystilbene (resveratrol) was purchased from Sigma-Aldrich Co. (St. Louis, MO). 4-(6-Hydroxy-2-naphthyl)-1,3-benzendiol (HS-1793) was supplied by Professor Hongsuk Suh (Pusan National University, Busan, Korea), and dissolved at a concentration of $100 \mathrm{mM}$ in ethanol as stock solution, stored $-20^{\circ} \mathrm{C}$. The stock solution was diluted with cell culture medium to the desired concentration prior to use. The maximal concentration of ethanol did not exceed $0.1 \%(\mathrm{v} / \mathrm{v})$ in the treatment range, where there was no influence on the cell growth (data not shown). The selective proteasome inhibitor, MG132, and protein synthesis inhibitor, cycloheximide (CHX), were from Sigma-Aldrich.

Cell culture. Human prostate cancer PC-3 cells were obtained from American Type Culture Collection (Manassas, VA). PC-3 cells was maintained in RPMI-1640 medium (HyClone, Logan, UT) in humidified atmosphere of $37^{\circ} \mathrm{C}$ with $5 \%$ $\mathrm{CO}_{2}$. RPMI-1640 supplemented with $10 \%$ heat-inactivated fetal bovine serum (FBS, HyClone), $2 \mathrm{mM}$ glutamine (Sigma-Aldrich), $100 \mathrm{U} / \mathrm{ml}$ penicillin (HyClone) and $100 \mu \mathrm{g} / \mathrm{ml}$ streptomycin (HyClone).

Hypoxia experiments. Experiments to investigate the effects of hypoxia were carried out in a hypoxia chamber of anaerobic system (Thormo, Marietta, $\mathrm{OH}$ ). Hypoxic condition was designated as $1 \% \mathrm{O}_{2}$ and $5 \% \mathrm{CO}_{2}$, temperature was maintained at $37^{\circ} \mathrm{C}$. Normoxia $\left(21 \% \mathrm{O}_{2}\right.$ and $\left.5 \% \mathrm{CO}_{2}\right)$ was defined as those conditions in a standard $\mathrm{CO}_{2}$ incubator. For hypoxia experiments, PC-3 cells were grown to $50 \%$ confluence in a standard $\mathrm{CO}_{2}$ incubator at $37^{\circ} \mathrm{C}$. Twenty-four hours prior to the experiment, cell culture media were placed in normoxic and hypoxic chambers to allow equilibration at corresponding condition. Immediately before each experiment, cell culture media were withdrawn from PC-3 cells and replaced with 
fresh media that were equilibrated at normoxic and hypoxic conditions for $24 \mathrm{~h}$.

MTT assay. Cell survival was quantified by MTT [(3-(4, 5-dimethylthiazol-2-yl)-2,5-diphenyltetrasolium bromide, Sigma-Aldrich)] assay which measures mitochondrial activity in viable cells. Cells seeded at a density of $1 \times 10^{5}$ per well plate were allowed to adhere overnight and then the culture media were replaced with fresh media. Cells were exposed to resveratrol or HS-1793 at concentrations of 25, 50 and $100 \mu \mathrm{M}$ for $6 \mathrm{~h}$ in both normoxia and hypoxia. Control groups were treated with ethanol equal to the highest percentage of $(<0.1 \%)$ solvent used in experimental conditions for MTT assay. After $6 \mathrm{~h}$ the medium was replaced with fresh medium. MTT was freshly prepared at $5 \mathrm{mg} / \mathrm{ml}$ in PBS and passed through a filter (pore size, $0.2 \mu \mathrm{m}$ ). An aliquot of $2 \mathrm{ml}$ of MTT stock solution was added to each well, and the plate was incubated at $37^{\circ} \mathrm{C}$ for $4 \mathrm{~h}$ in a humidified $5 \% \mathrm{CO}_{2}$. After $4 \mathrm{~h}$, media were removed. To each well, $2 \mathrm{ml}$ of DMSO was added in order to solubilize the formazan, which was measured after $10 \mathrm{~min}$. The optical density of each well was measured with a spectrophotometer equipped with a 540-nm filter.

Protein preparation and western blot analysis. Cells were harvested and washed twice in PBS at $4^{\circ} \mathrm{C}$. Total cell lysates were lysed in lysis buffer [40 mM Tris ( $\mathrm{pH} 8.0), 120 \mathrm{mM}$, $\mathrm{NaCl}, 0.5 \% \mathrm{NP}-40,0.1 \mathrm{mM}$ sodium orthovanadate, $2 \mu \mathrm{g} / \mathrm{ml}$ aprotinin, $2 \mu \mathrm{g} / \mathrm{ml}$ leupeptin and $100 \mu \mathrm{g} / \mathrm{ml}$ phenymethylsulfonyl fluoride (PMSF)]. The supernatant was collected and protein concentrations were then measured with protein assay reagents (Pierce, Rockford, IL, USA). Equal amount of protein extracts were denatured by boiling at $95^{\circ} \mathrm{C}$ for $5 \mathrm{~min}$ in sample buffer (0.5 M Tris-HCl, pH 6.8, 4\% SDS, 20\% glycerol, $0.1 \%$ bromophenol blue, $10 \% \beta$-mercaptoethanol) in ratio of 1:1. Equal amount of the total proteins were subjected to $6-15 \%$ SDS-PAGE and transferred to polyvinylidene difluoride membranes. The membranes were blocked with $5 \%$ non-fat dry milk in Tris-buffered saline with Tween-20 buffer (TBS-T) (20 mM Tris, $100 \mathrm{mM} \mathrm{NaCl,pH} 7.5$ and $0.1 \%$ Tween-20) for $1 \mathrm{~h}$ at room temperature. Then, the membranes were incubated overnight at $4{ }^{\circ} \mathrm{C}$ with the primary antibodies. The membranes were washed once for $10 \mathrm{~min}, 3$ times with TBS-T buffer and incubated for $1 \mathrm{~h}$ with horseradish peroxidase-conjugated anti-rabbit or anti-mouse immunoglobin (Santa Cruz Biotechnology Inc., Santa Cruz, CA). The membranes were washed once for $10 \mathrm{~min}, 4$ times with TBS-T buffer. Antigen-antibody complexes were detected by the enhanced chemiluminescence (ECL) detection system (GE Healthcare Biosciences, Pittsburgh, PA).

ELISA assay. To analyze VEGF secretion, PC-3 cells were seeded in 12 -well plates, cultured to $\sim 50 \%$ confluence, pretreated with resveratrol, HS-1793 or ethanol control for $30 \mathrm{~min}$ and switched to fresh media pre-conditioned at normoxia or hypoxia. Cells were incubated in the presence or absence of resveratrol or HS-1793 at corresponding conditions for $24 \mathrm{~h}$. The supernatants in the wells were collected, cleared by centrifugation and stored at $-20^{\circ} \mathrm{C}$. ELISA was performed using the human VEGF Quantikine kit (R\&D Systems, Minneapolis, $\mathrm{MN}$ ) according to company protocol. Recombinant human
VEGF was used for calibration. Experiments were carried out at least three times in triplicates.

$R N A$ extraction and reverse transcription-PCR. For reverse transcription PCR analysis, total RNA was extracted from cultured cells using an RNeasy mini kit reagent as described by the manufacturer (Quiagen, La Jolla, CA). PCR amplification cDNA was prepared using a Bioneer RT/PCR PreMix containing 1 unit Taq DNA polymerase, $250 \mu \mathrm{M}$ dNTPs, $10 \mathrm{mM}$ Tris- $\mathrm{HCl}$, $40 \mathrm{mM} \mathrm{KCl}, 1.5 \mathrm{mM} \mathrm{MgCl}$ (Bioneer, Seoul, Korea). The assay was carried out in a $20 \mu \mathrm{l}$ reaction mixture containing $1 \mu \mathrm{g}$ of total RNA, 30 pmol of each primer, $1 \mu \mathrm{g}$ Oligo dT (Bioneer), using a PCR Thermal Cycler Dice Takara TP600 (Takara, Otsu, Japan). The resulting complementary DNA was amplified with the following sets of primers. Oligonucleotide primers for individual markers were synthesized as follows: HIF-1 $\alpha$ (sense 5'-CTTGCTCATCAGTTGCCACTT-3', antisense 5'-GCCAT TTCTGTGTGTAAGCAT-3'); VEGF (sense 5'-AGGAGGGC AGAATCATCACG-3', antisense 5'-CAAGGCCCACAGGG ATTTTCT-3'), GAPDH (sense 5'-CGGAGTCAACGGATT TGGTCGTAT-3', antisense 5'-AGCCTTCTCCATGGTGGT GAAGAC-3'). GAPDH served as an internal control. The cycling conditions were as follows: cDNA synthesis at $42^{\circ} \mathrm{C}$ for $60 \mathrm{~min}$, RTase inactivation at $94^{\circ} \mathrm{C}$ for $5 \mathrm{~min}, 1 \mathrm{X}$ denaturation $\left(94^{\circ} \mathrm{C}\right.$ for $\left.30 \mathrm{~s}\right), 30 \mathrm{X}$ annealing $\left(58^{\circ} \mathrm{C}\right.$ for $\left.30 \mathrm{~s}\right)$, and $1 \mathrm{X}$ extension $\left(72^{\circ} \mathrm{C}\right.$ for $1 \mathrm{~min}$ ) for 30 cycles. PCR products were analyzed by electrophoresis on 1.5\% agarose gel (Bio Basic Inc., Markham, ON, Canada) in the presence of ethidium bromide (Sigma-Aldrich), and were visualized with a UV transilluminator (MultiImage ${ }^{\mathrm{TM}}$ Light Cabinet, Alpha Innotech Co., San Leandro, CA).

Wound healing assay. The cells were grown to confluence in 6-well plates for 1 day, and a scrape in the form of a cross was made through the confluent monolayer with a plastic pipette tip. The cells were treated with resveratrol or HS-1793 for $1 \mathrm{~h}$ under normoxic condition, and then transferred to hypoxic condition for $24 \mathrm{~h}$. Several wounded areas were marked for orientation, observed, and the photographed by microscopy (x50 magnification) at $24 \mathrm{~h}$ after the scratch.

In vitro migration assay. Cell migration assay was performed by using 24-well modified Boyden chambers (Corning Life Science, Corning, NY). Cell migration kit was used for the cell migration assay according to the manufacture's protocol. Confluent cells were added to the inner chamber of the insert in $100 \mu \mathrm{l}$ of serum-free medium. Medium $(600 \mu \mathrm{l})$ with $10 \%$ FBS was added to the lower chamber. To determine the effect of HS-1793 on cell migration, resveratrol and HS-1793 with a final concentration of $5 \mu \mathrm{M}$ was added to the lower chamber and ethanol was used as a control. Cells were then fixed and stained with Diff-Quick Stain kit (Baxter, McGaw Park, IL), following the procedure described by the manufacturer. The number of migrating cells was counted under a microscope (x200 magnification) and the results were expressed as the percentage of number of invaded cells per field for each condition.

Statistical analysis. Results were expressed as the mean \pm SD of three separate experiments and analyzed by Student's t-test. The mean was considered significantly different at $\mathrm{p}<0.05$ or $\mathrm{p}<0.01$. 

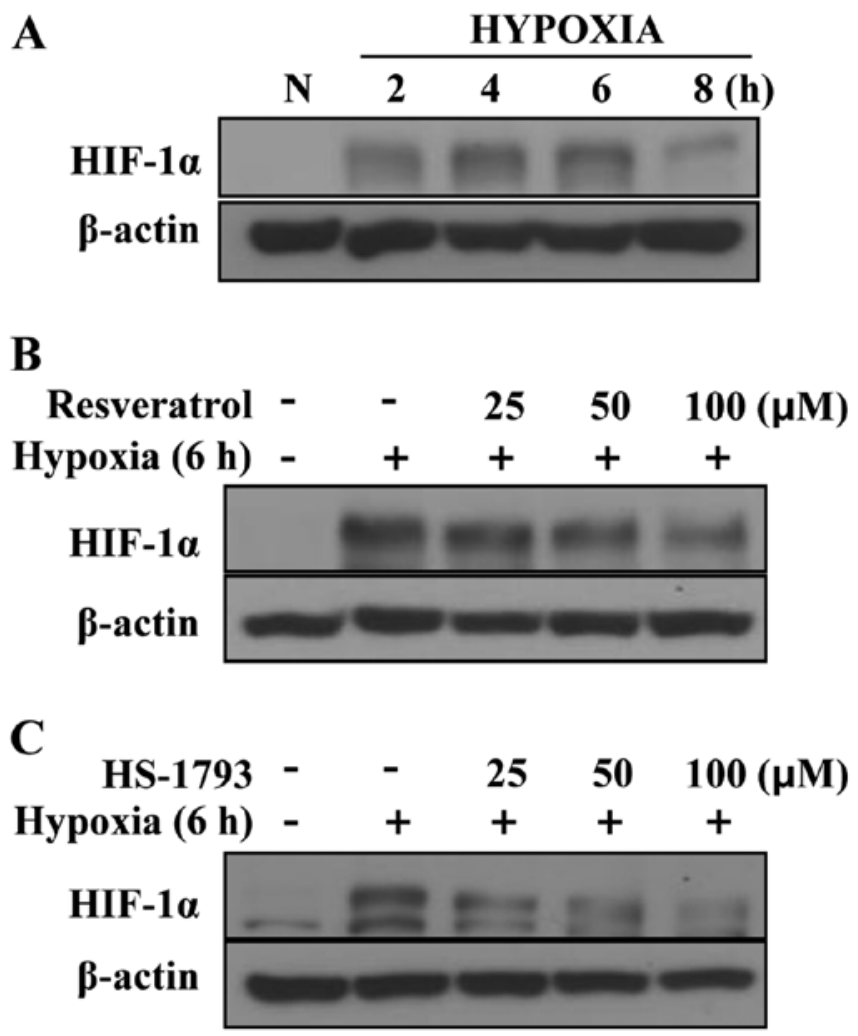

Figure 2. Effects of resveratrol and HS-1793 on the expression of HIF-1 $\alpha$ protein under hypoxic condition in PC-3 cells. (A) The cells were incubated at various time points in hypoxia chamber. Cells were exposed to $1 \% \mathrm{O}_{2}$ in combination with various concentrations (25-100 $\mu \mathrm{M})$ of (B) resveratrol or (C) HS-1793 for $6 \mathrm{~h}$. Total cell lysates were prepared and subjected to western blot analysis using corresponding antibodies. Representative results from three independent experiments are shown. $\beta$-actin was used as a loading control. $\mathrm{N}$, normoxia.

\section{Results}

Hypoxic condition induces HIF-1 $\alpha$ protein in $\mathrm{PC}-3$ cells. To investigate the effects of hypoxia induced HIF-1 $\alpha$ in PC-3 cells, cells were grown to $70 \%$ confluence in a standard $\mathrm{CO}_{2}$ incubator at $37^{\circ} \mathrm{C}$ (normoxic conditions of $21 \% \mathrm{O}_{2}, 5 \% \mathrm{CO}_{2}$ ) and then transferred to the hypoxia chamber $\left(1 \% \mathrm{O}_{2}\right.$, and $5 \% \mathrm{CO}_{2}$ ). Cultures were exposed to hypoxia and harvested at various time points $(2,4,6$ and $8 \mathrm{~h})$. The results demonstrate that hypoxia dramatically induced HIF- $1 \alpha$ protein expression in PC-3 cells (Fig. 2A). HIF-1 $\alpha$ protein induction was observed in cells $2 \mathrm{~h}$ after switching to hypoxia, and become pronounced between 2-8 h under hypoxic conditions, reaching peaks between 4 and $6 \mathrm{~h}$, and $6 \mathrm{~h}$ time point was selected for further experiments.

HS-1793 inhibits hypoxia-induced HIF-1a in PC-3 cells. Next, we investigated whether HS-1793 was able to suppress the observed responses to hypoxia in PC-3 cells. Cells were pretreated with medium containing $25-100 \mu \mathrm{M}$ resveratrol or HS-1793 for $1 \mathrm{~h}$ at normoxia then transferred into hypoxia chamber. Cells were exposed to hypoxia for $6 \mathrm{~h}$ and then washed with PBS and lysed inside the chamber. Resveratrol treatment significantly inhibited HIF-1 $\alpha$ levels by 20,50 and $75 \%$ at 25 , 50 and $100 \mu \mathrm{M}$, respectively (Fig. 2B). HS-1793 treatment also significantly inhibited HIF-1 $\alpha$ levels by 50,55 and $85 \%$ at 25 ,

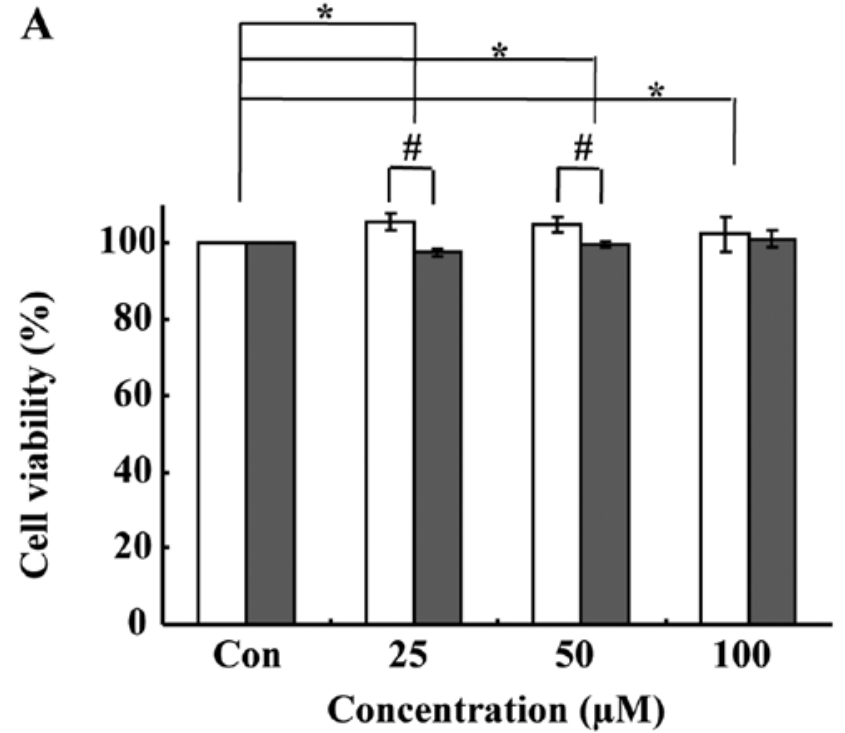

B

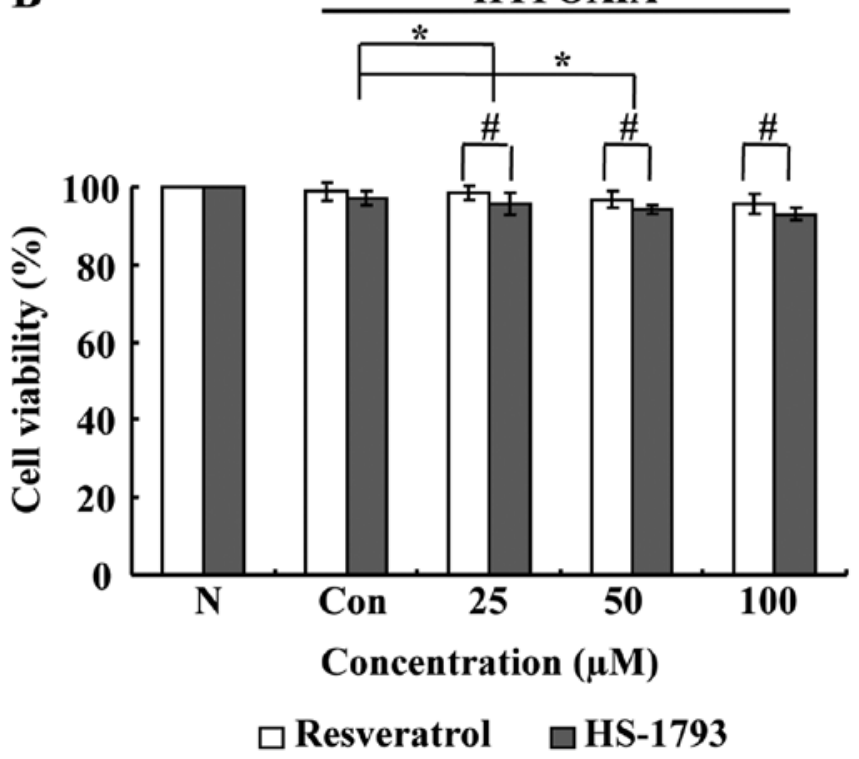

Figure 3. Effects of resveratrol and HS-1793 on the cell viability. Cells were treated with resveratrol or HS-1793 for $6 \mathrm{~h}$ under (A) normoxic or (B) hypoxic conditions. Cell viability was determined by MTT assay. Results are expressed as percentages of the vehicle-treated control $\pm \mathrm{SD}$ of three separate experiments. The significance was determined by Student's t-test ( $\mathrm{p} p<0.05$ vs. vehicle-treated control; " $\mathrm{p}<0.05$ vs. resveratrol). $\mathrm{N}$, normoxia; Con, control.

50 and $100 \mu \mathrm{M}$, respectively, compared to non-treatment cells (Fig. 2C). Moreover, HS-1793 inhibited HIF-1 $\alpha$ expression more than resveratrol in $\mathrm{PC}-3$ cells. This result showed that HS-1793 is more effective than resveratrol in inhibiting the expression of HIF-1 $\alpha$ in PC-3 cells.

Decreased HIF-1a protein level is not due to cell death. To investigate the effects of HS-1793 induced cytotoxicity under normoxic and hypoxic conditions and whether cytotoxicity is responsible for suppression of HIF-1 $\alpha$ accumulation, cell viability was determined by MTT assay. When PC-3 cells were treated with various concentrations of resveratrol or HS-1793 


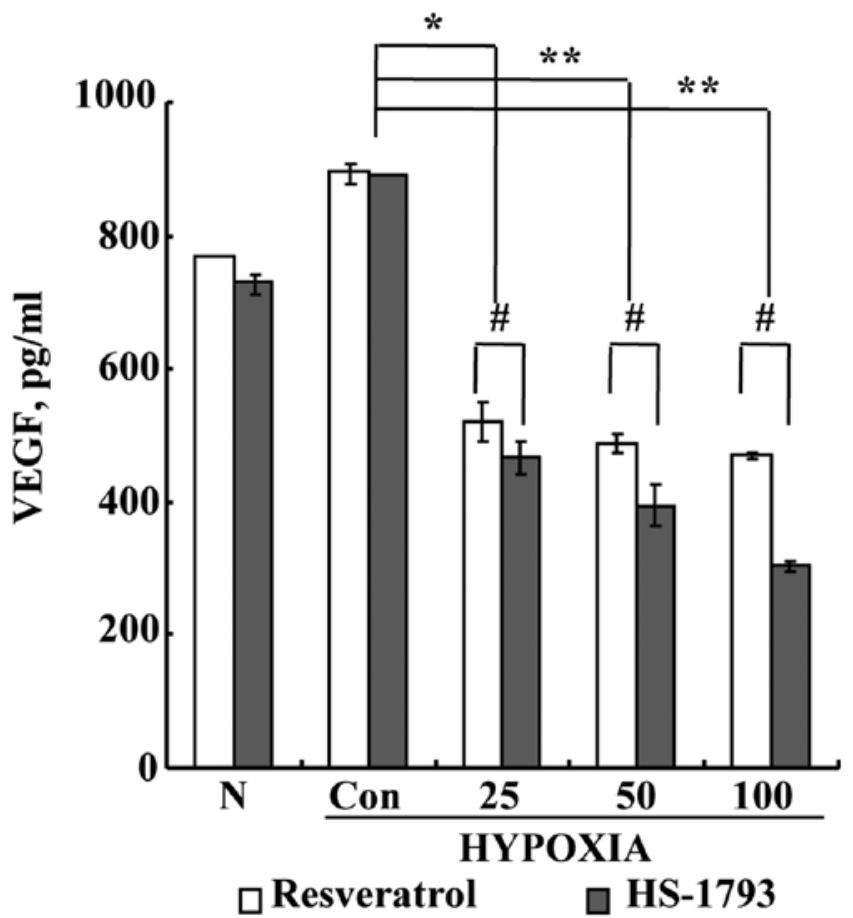

Figure 4. Effects of resveratrol and HS-1793 on the VEGF expression under hypoxic condition in PC-3 cells. PC-3 cells were treated with various concentrations of resveratrol or HS-1793 $(25-100 \mu \mathrm{M})$ for $24 \mathrm{~h}$ in hypoxic condition. The concentration of VEGF level in the culture media was determined by ELISA. The assays were performed with triplicate experimental samples. Results were expressed as percentages of the vehicle-treated control $\pm \mathrm{SD}$ of three separate experiments. The significance was determined by Student's t-test $\left({ }^{*} \mathrm{p}<0.05,{ }^{* *} \mathrm{p}<0.01\right.$ vs. vehicle-treated control; ${ }^{*} \mathrm{p}<0.05$ vs. resveratrol). $\mathrm{N}$, normoxia; Con, control.

(25-100 $\mu \mathrm{M}$ ) for $6 \mathrm{~h}$ in normoxic and hypoxic conditions, no significant concentration-dependent reduction of the viability was observed (Fig. 3A and B). These data show that the decrease of HIF-1 $\alpha$ is not due to cell death at both normoxic and hypoxic conditions.

HS-1793 downregulates hypoxia-induced VEGF expression. VEGF is one of the target genes of HIF-1, which plays a crucial role in tumor angiogenesis. HIF-1 regulates the expression of VEGF at the transcriptional level (25). To determine whether HS-1793 inhibits VEGF expressions in PC-3 cells, VEGF levels were measured by ELISA kit. Cells were incubated at hypoxic conditions in the absence or presence of $25-100 \mu \mathrm{M}$ resveratrol or HS-1793. Twenty-four hours later, cell culture media were collected and the VEGF level was analyzed. VEGF levels were increased under hypoxic condition. However, VEGF induction was decreased concentration-dependently by treatment with resveratrol or HS-1793 (Fig. 4). HS-1793 more efficiently inhibited VEGF expression than resveratrol in PC-3 cells. This result showed that HS-1793 is more effective than resveratrol in inhibiting the expression of VEGF in PC-3 cells.

HS-1793 does not affect hypoxia-induced VEGF mRNA expression. As the downregulation of HIF-1 $\alpha$ protein levels by resveratrol and HS-1793 would be caused by a decrease in its mRNA level, the effects of HS-1793 and resveratrol on the expression of HIF-1 $\alpha$ mRNA levels under hypoxic condition
A
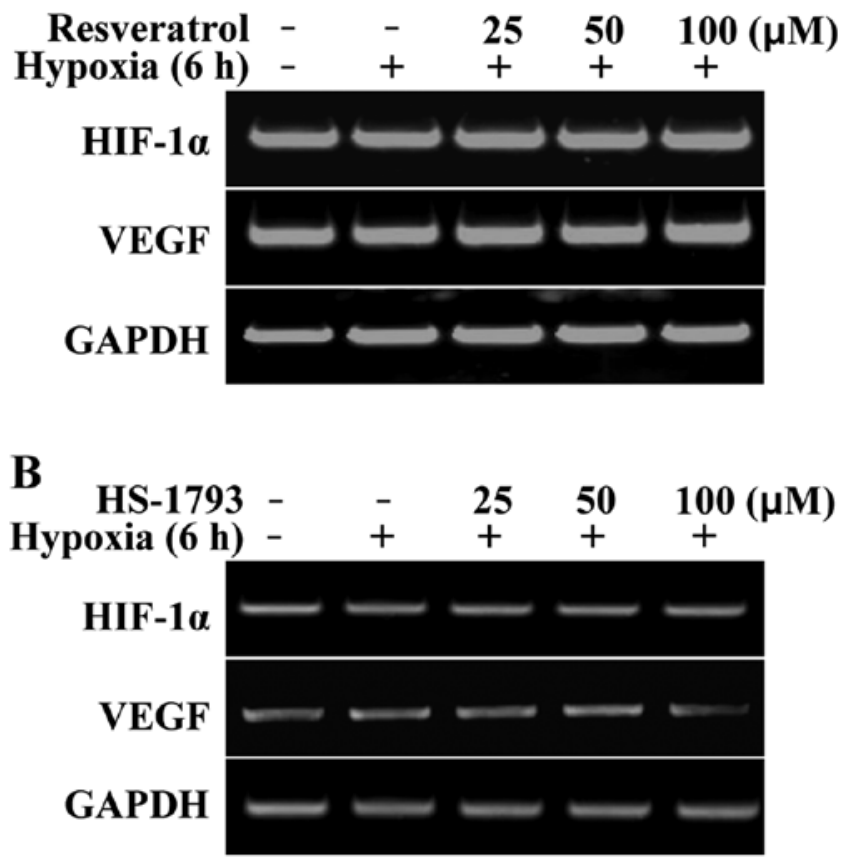

Figure 5. Effects of resveratrol and HS-1793 on the level of HIF-1 $\alpha$ and VEGF mRNA under hypoxic condition in PC-3 cells. The cells were exposed to $1 \% \mathrm{O}_{2}$, treated with various concentrations of (A) resveratrol and (B) HS-1793 for $6 \mathrm{~h}$. Total mRNA was extracted and subjected to reverse transcriptionPCR analysis. Representative results from three independent experiments are shown. GAPDH was used as a loading control.

were measured by reverse transcriptional-PCR. The cells were pretreated with medium containing $25-100 \mu \mathrm{M}$ resveratrol or HS-1793 for $1 \mathrm{~h}$ at normoxia then transferred hypoxia chamber and exposed to hypoxia for another $6 \mathrm{~h}$, then mRNA sample was collected. As shown in Fig. 5A, resveratrol did not affect HIF-1 $\alpha$ and VEGF mRNA expression under hypoxic conditions, neither did HS-1793 affect HIF-1 $\alpha$ and VEGF mRNA expression under hypoxic condition in PC-3 cells (Fig. 5B). These results indicated that the inhibition of HIF-1 $\alpha$ expression under hypoxic condition by resveratrol or HS-1793 was not through the reduction of mRNA level, suggesting posttranscriptional mechanisms of resveratrol or HS-1793 actions on HIF-1 $\alpha$ expressions.

HS-1793 inhibition of PI3K/Akt signaling pathway is involved in downregulation of HIF-la protein. Previous studies have shown that multiple signaling pathways, particularly phosphatidylinositol 3-kinase (PI3K)/Akt and MAPK/ERK are involved in hypoxia-induced HIF-1 $\alpha$ protein accumulation and its downstream target gene expression (26). To explore whether HS-1793 can inhibit hypoxia-mediated activation of Akt, PC-3 cells were pretreated with various concentrations of resveratrol or HS-1793 for $1 \mathrm{~h}$ in normoxia, followed by incubation under hypoxia for $6 \mathrm{~h}$, and then cells were washed with PBS and lysed inside the chamber. Resveratrol and HS-1793 affected the phosphorylated Akt levels in a concentration-dependent manner (Fig. 6A and B). To check whether HIF-1 $\alpha$ or Akt activation was due to hypoxia, LY294002, a commonly used PI3K inhibitor, was used. LY294002 significantly blunted the elevation of HIF-1 $\alpha$, pAkt protein levels when cells were exposed 
A

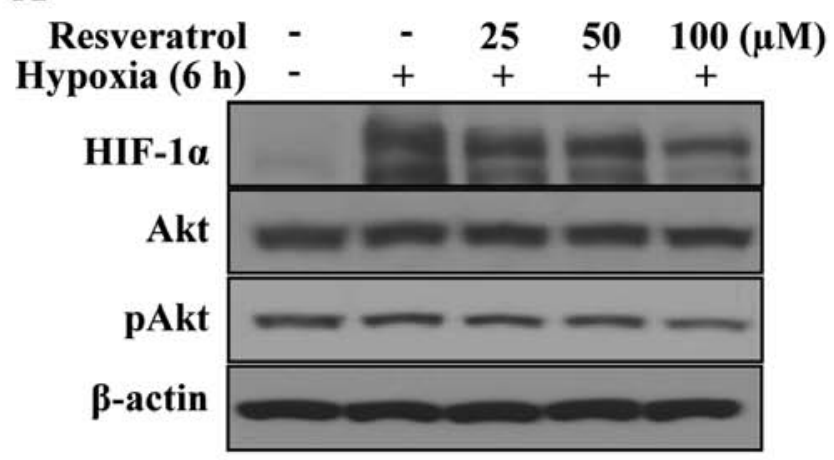

B

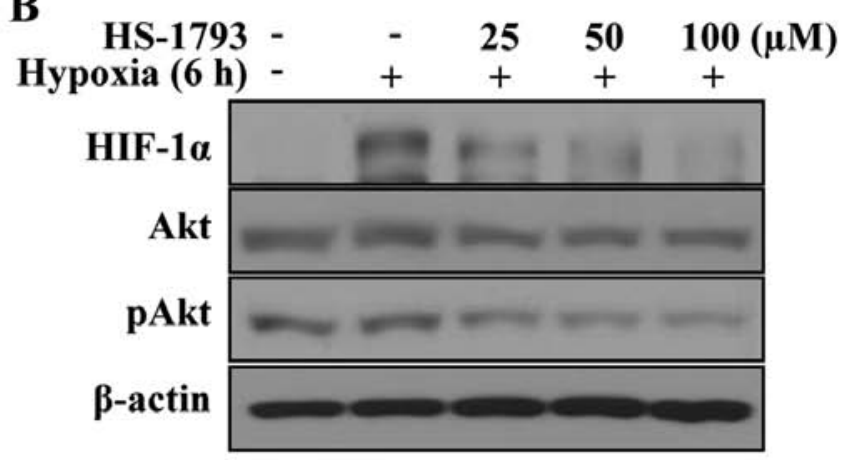

C

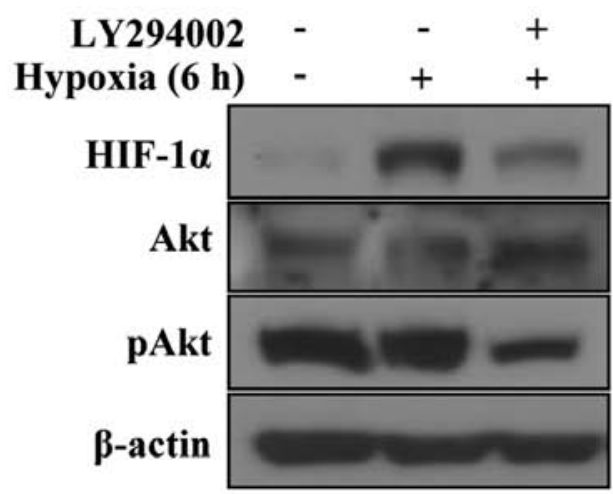

Figure 6. Role of PI3K in the accumulation of HIF-1 $\alpha$ in PC-3 cells. Cells were exposed to $1 \% \mathrm{O}_{2}$, treated with various concentrations of (A) resveratrol, (B) HS-1793 and (C) LY294002 for $6 \mathrm{~h}$. Total cell lysates were prepared and subjected to western blot analysis using corresponding antibodies. Representative results from three independent experiments are shown. $\beta$-actin was used as a loading control.

to hypoxia (Fig. 6C). These results show that the decrease of HIF-1 $\alpha$ under hypoxic condition in PC-3 cells is related to the regulation of $\mathrm{PI} 3 \mathrm{~K}$ pathway.

HS-1793 degrades HIF-1 $\alpha$ protein via the proteasome pathway. To examine whether HS-1793 induced HIF-1 $\alpha$ protein degradation is mediated by the proteasome degradation pathway, cells were treated with proteasome inhibitor MG132 for $30 \mathrm{~min}$ and then treated with medium containing resveratrol or HS-1793 for $30 \mathrm{~min}$. Next, cells were exposed to hypoxia for $6 \mathrm{~h}$, cells were then washed with PBS and lysed inside the chamber. The degradation of HIF-1 $\alpha$ protein with resveratrol or HS-1793 treatment was completely prevented
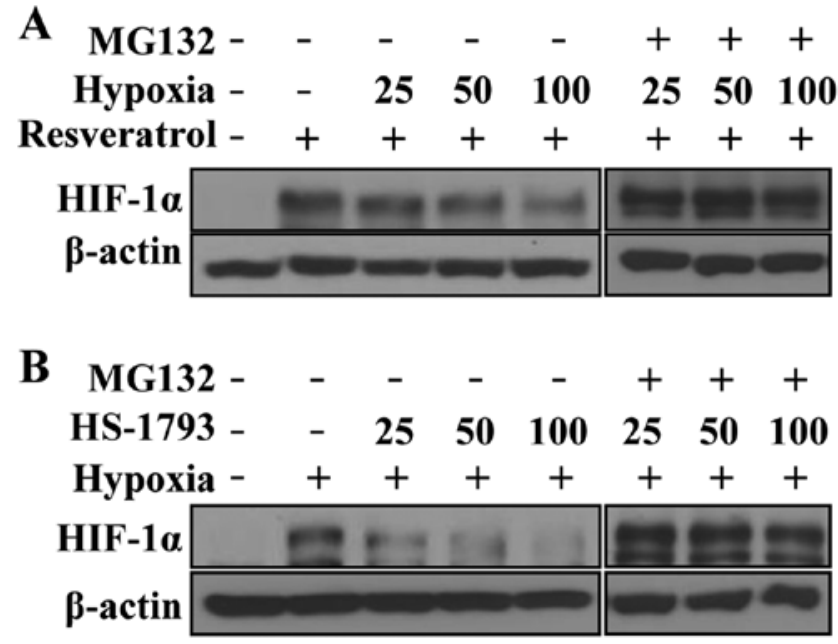

Figure 7. Effects of resveratrol and HS-1793 on HIF-1 $\alpha$ protein degradation. Cells were exposed to $1 \% \mathrm{O}_{2}$ and treated with (A) resveratrol or (B) HS-1793 for $6 \mathrm{~h}$ in the presence or absence of $20 \mu \mathrm{M}$ MG132. Total cell lysates were prepared and subjected to western blot analysis using corresponding antibodies. Representative results from three independent experiments are shown. $\beta$-actin was used as a loading control.

by MG132 (Fig. 7A and B). These data indicate that HS-1793 induced HIF-1 $\alpha$ protein degradation through the proteasome degradation pathway.

$H S-1793$ affects stability of HIF-1 $\alpha$ protein. To evaluate the mechanism by which resveratrol and HS-1793 inhibit the expressions of HIF-1 $\alpha$, cells were exposed to hypoxia to induce HIF-1 $\alpha$ protein. This step was necessary because very little HIF-1 $\alpha$ is detectable under normoxic conditions due to rapid protein degradation. Cycloheximide (CHX), a protein synthesis inhibitor, is widely used in protein stability studies. Cells were incubated for $6 \mathrm{~h}$ in hypoxic condition and treated with $\mathrm{CHX}$ for an additional $30 \mathrm{~min}$ in the presence or absence of $50 \mu \mathrm{M}$ resveratrol or HS-1793. Cells were harvested at various time points and cell lysates were analyzed by western blot analysis using anti-HIF-1 $\alpha$ antibody. Under hypoxic conditions, the half-life of HIF-1 $\alpha$ was determined to be over $4 \mathrm{~h}$ when the cells were treated with $\mathrm{CHX}$ alone or in combination with resveratrol and $1 \mathrm{~h}$ when treated with HS-1793 (Fig. 8A-C). The half-life of HIF-1 $\alpha$ was determined to be 4 and $2 \mathrm{~h}$ when treated with $\mathrm{CHX}$ and resveratrol or when treated with CHX and HS-1793, respectively (Fig. 8D). These data showed that resveratrol and HS-1793 treatment reduced the half-life of HIF- $1 \alpha$ protein under hypoxic conditions, indicating that, mechanisms by which resveratrol and HS-1793 treatment regulate HIF-1 $\alpha$ expression is by decreasing protein stability. These results suggest that HS-1793 affected hypoxia-induced HIF-1 $\alpha$ protein stability in PC-3 cells. Moreover, HS-1793 is more effective in hypoxia-induced $\mathrm{HIF}-1 \alpha$ protein stability in PC-3 cells.

HS-1793 inhibits hypoxia-induced migration. Hypoxic condition has been shown to stimulate migration in various cancer cells, including ovarian cancer cells and resveratrol reduced hypoxia-induced migration (27). To determine whether HS-1793 inhibits motility of PC-3 cells, wound-healing experi- 
A

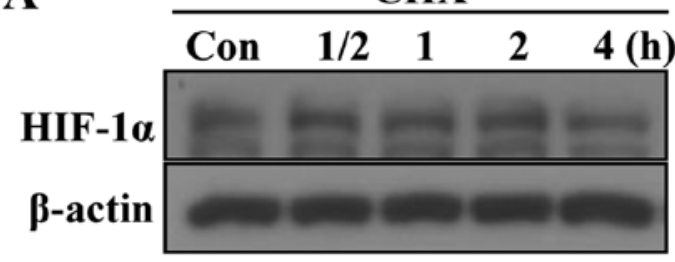

B
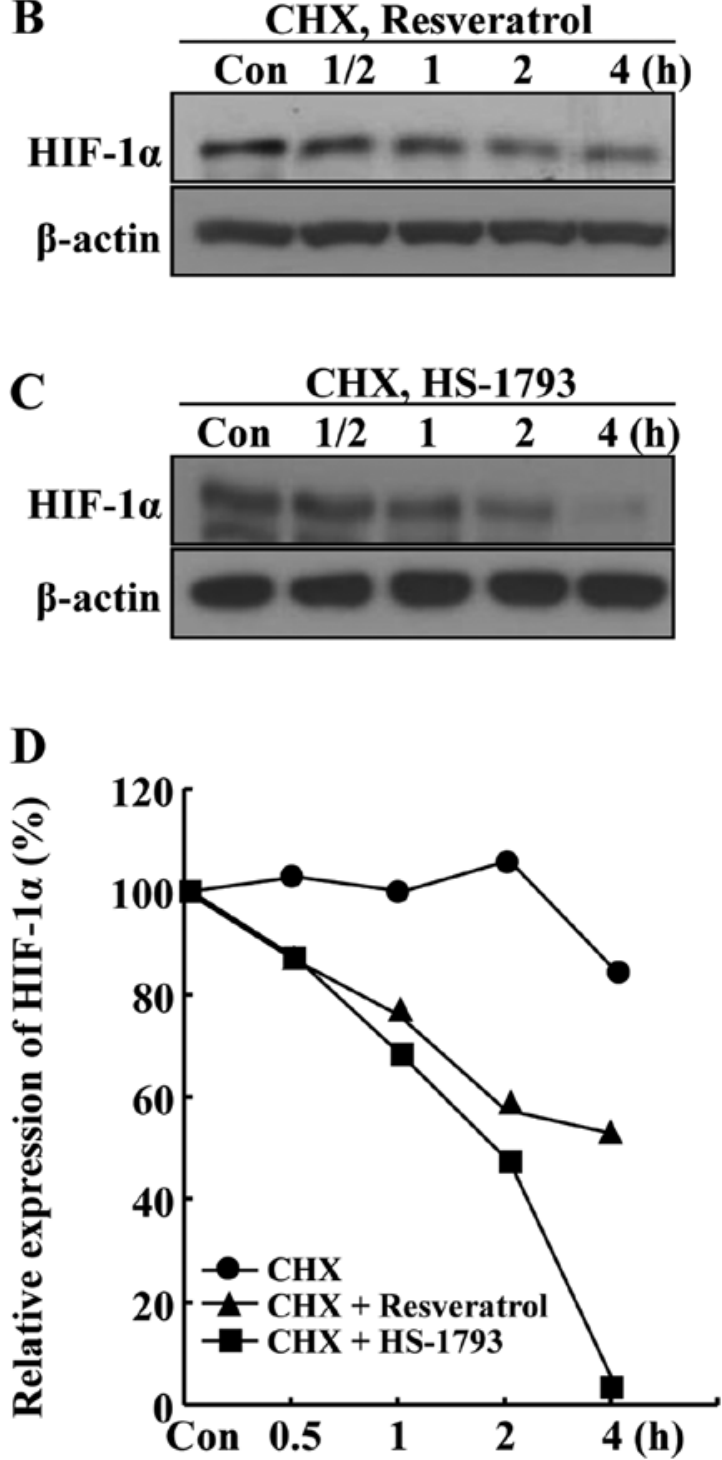

Figure 8. Effects of resveratrol and HS-1793 on HIF-1 $\alpha$ protein stability. (A) After PC-3 cells were exposed to hypoxic conditions to induce HIF-1 $\alpha$ for $6 \mathrm{~h}$, cells were treated with cycloheximide ( $\mathrm{CHX}$ ) for $30 \mathrm{~min}$, and then treated with (B) resveratrol and (C) HS-1793 for various time points. All steps were in hypoxic conditions. Total cell lysates were prepared and subjected to western blot analysis using corresponding antibodies. Representative results from three independent experiments are shown. $\beta$-actin was used as a loading control (D) Relative expression of HIF-1 $\alpha$ measured by fluorchem SP. Con, control.

ments were performed. In hypoxic conditions, PC-3 cells had increased motility compared to normoxic conditions (Fig. 9A). As shown in Fig. 9B and C, resveratrol and HS-1793 inhibited motility in hypoxic conditions. In hypoxic conditions, scratch area was decreased due to hypoxia-induced motility compared

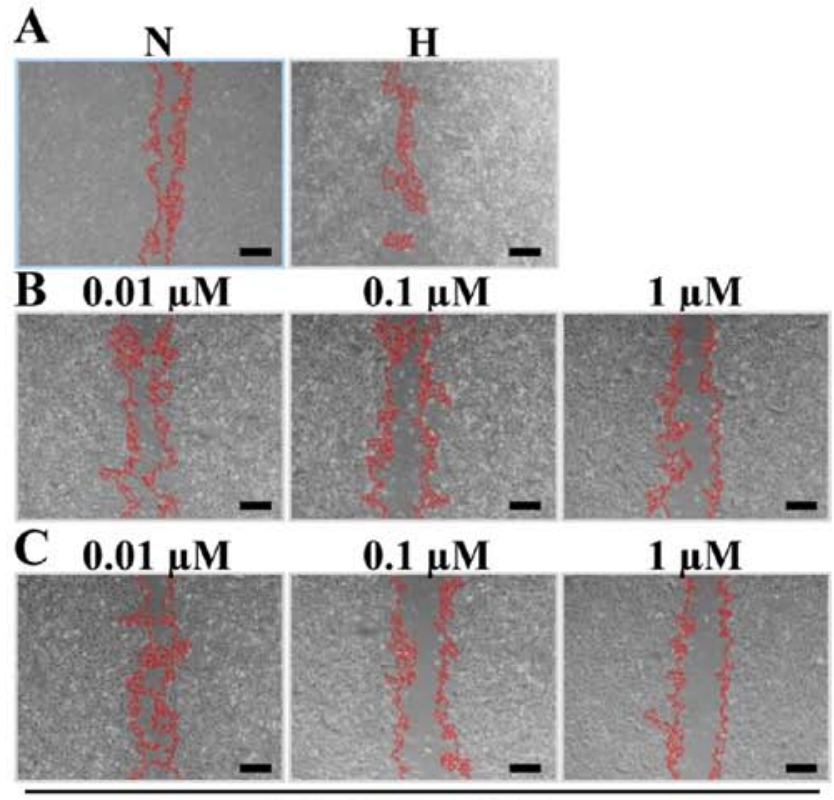

HYPOXIA (24 h)

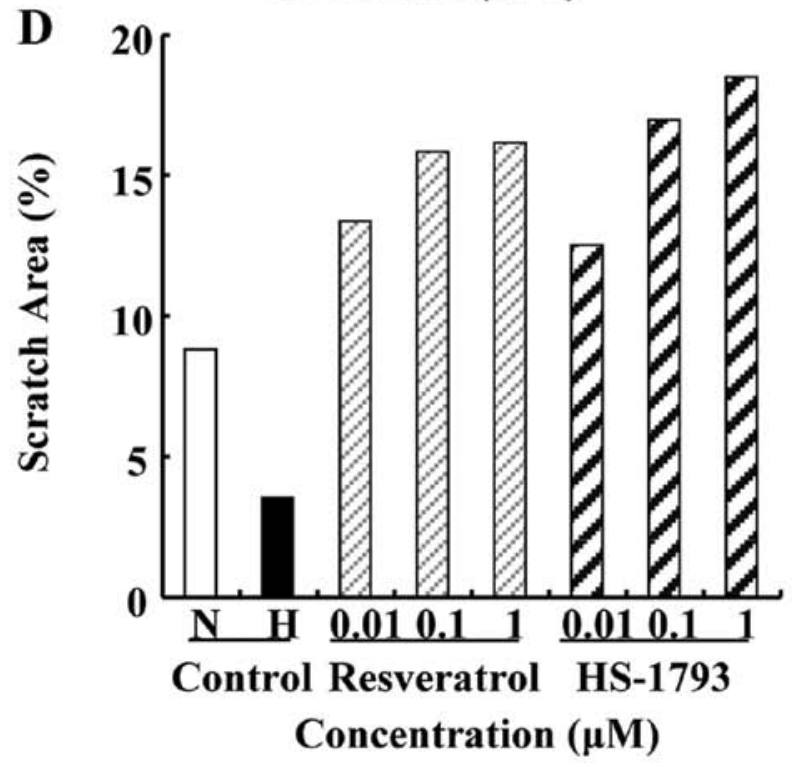

Figure 9. Effects of resveratrol and HS-1793 on hypoxia-induced motility. The cells were cultured in normal growth medium to sufficient confluence, then changed to $1 \%$ FBS medium and then a scrape in the form of a cross was made through the confluent monolayer with a plastic pipette tip. (A) Cells were incubated in both normoxic and hypoxic conditions for $24 \mathrm{~h}$. Cells were treated with (B) resveratrol or (C) HS-1793 and incubated for $24 \mathrm{~h}$ under hypoxic conditions. Several wounded areas were marked and then photographed by a microscope, and the surface (scratch) areas were analyzed with the cell motility software (www.muscale.com). Bars represent $200 \mu \mathrm{m}$. (D) Scratch areas are displayed as bar graphs. $\mathrm{N}$, normoxia; $\mathrm{H}$, hypoxia.

to normoxic conditions. Scratch areas were increased by 15 and $20 \%$ at treated with resveratrol or HS-1793, respectively, compared to that of hypoxic conditions (Fig. 9D). HS-1793 is more effective in hypoxia-induced motility in PC-3 cells. These working concentration did not reveal cytotoxicity (data not shown). We also tested whether HS-1793 affected PC-3 cell migration activity in vitro. PC-3 cells were treated with resveratrol or HS-1793 in the presence or absence of hypoxic condition. As shown in Fig. 10A, there was little cell migra- 

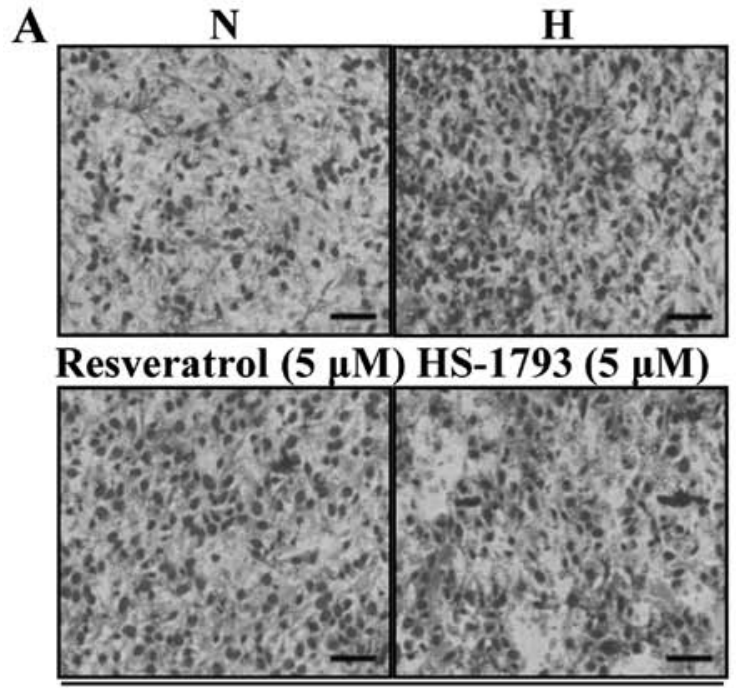

HYPOXIA (24 h)

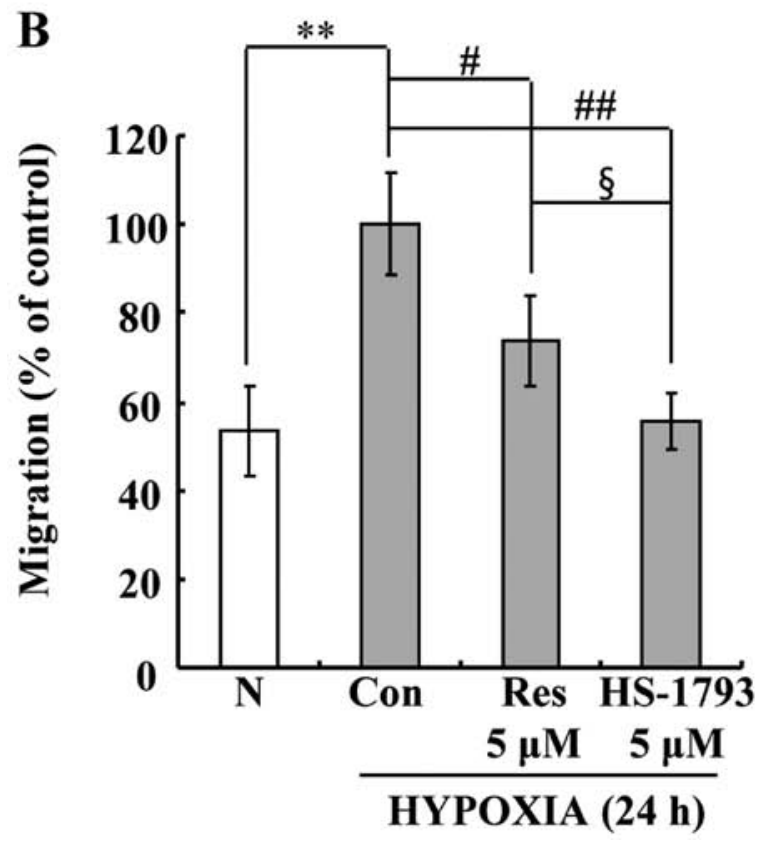

Figure 10. HS-1793 inhibits hypoxia-induced migration in PC-3 cells. (A) For migration assay, the cells were placed in the upper chamber inserts with the indicated concentrations of resveratrol or HS-1793 and allowed to migrate for $24 \mathrm{~h}$. Membranes containing migrated cells were stained, and 10 random fields from each experiment were counted under a microscope Bars represent $100 \mu \mathrm{m}$. Representative results from three independent experiments are shown. (B) Migration activity was displayed as bar graphs. The significance was determined by Student's t-test $\left({ }^{* *} \mathrm{p}<0.01\right.$ vs. normoxia; ${ }^{\#} \mathrm{p}<0.05,{ }^{\# \#} \mathrm{p}<0.01$ vs. vehicle-treated control; ${ }^{\circledR} \mathrm{p}<0.05$ vs. resveratrol). The results are represented as the mean $\pm \mathrm{SD}$ of three independent experiments. $\mathrm{N}$, normoxia; H, hypoxia; Con, control.

tion under normoxia. However, under hypoxic conditions cell migration increased. Resveratrol or HS-1793 treatment decreased migration activity. Migration was inhibited by 20 and $40 \%$ with treatment of $5 \mu \mathrm{M}$ of resveratrol and HS-1793, respectively. Treatment of HS-1793 shows more effective prevention of the cell migration than resveratrol in PC-3 cells (Fig. 10B).

\section{Discussion}

Although resveratrol is photosensitive and its stilbene double bonds are readily oxidized, its interesting anticancer activity offers promise for the rational design of new chemotherapeutic agents. HS-1793, in comparison to resveratrol, shows more potent activities, such as growth inhibition, downregulation of HIF-1 $\alpha$ and VEGF expressions, and inhibition of hypoxia-induced migration of PC-3 human prostate cancer cells.

Angiogenesis, sprouting new blood vessels from existing endothelium, is essential for wound repair, organ regeneration, embryonic vascular system development and a variety of pathological conditions, including tumor angiogenesis and liver fibrosis (28). The tumor growth, development and metastasis are dependent on angiogenesis, especially for the solid tumors (29). Increased angiogenesis has been shown to be associated with the tumor development of metastasis, poor prognosis and reduced survival. In addition, anti-angiogenic agents, if administered before a tumor develops or becomes vascular supply-dependent, would therefore theoretically act similar to a vaccine in preventing tumor development, not only the tumor growth (30). Therefore, understanding the mechanisms of angiogenesis regulation could provide new therapeutic options for cancer treatment.

The mechanism-based efficacy without any considerable side-effect is an essential requirement for the clinical development of a cancer chemopreventive agent. In prostate cancer, ligand-induced signaling often drives cell proliferation and survival, which are accompanied by deregulated cell cycle progression (31). Many signaling pathways are constitutively active leading to persistent growth and progression in human prostate cancer. In this manner, human prostate cancer cells keep accumulating neoplastic genetic and epigenetic changes leading to the metastatic disease. Furthermore, angiogenesis has been observed as an obligatory requirement for the solid tumor growth, including prostate tumors (32). In view of these facts, HIF-1 $\alpha$ could be a logical chemopreventive target to control prostate cancer cell-derived angiogenesis.

Resveratrol has been extensively researched for its powerful antioxidant capacity and other biological effects (33). However, resveratrol is unstable and its stilbene double bonds are readily oxidized, the simplicity of resveratrol, associated with its interesting anticancer activity, offers promise for the rational design of new chemotherapeutic agents. A novel resveratrol analogue, HS-1793, does not contain the unstable double bond which resveratrol has. In addition, the position of two of the three hydroxyl groups in HS-1793 at the aromatic ring is different from resveratrol.

HIF-1 $\alpha$ protein level is tightly regulated by oxygen tension via the ubiquitination and $26 \mathrm{~S}$ proteasomal degradation system. Under hypoxic conditions, the ubiquitination and degradation of HIF-1 $\alpha$ protein is inhibited, thus leading to the stabilization and accumulation of HIF-1 $\alpha$ protein (34). In this study, HS-1793 inhibited the level of HIF-1 $\alpha$ protein expression in PC-3 cells (Fig. 2C) and significantly shortened the half-life of hypoxia-induced HIF-1 $\alpha$ protein (Fig. 8C). Moreover, HS-1793 data showed that the inhibition of hypoxia-induced HIF-1 $\alpha$ protein accumulation by HS-1793 was abolished in the 
presence of MG132, a potent inhibitor of the 26S proteasome (Fig. 7B). Thus, HS-1793 inhibited HIF-1 $\alpha$ protein expression via interfering both protein translation and HIF-1 $\alpha$ protein degradation. However, to understand the mechanism by which HS-1793 exerts potent anti-angiogenic activity, further studies are required.

Previous studies have shown that hypoxia stimulates the activation of several signaling pathways, particularly PI3K/Akt (35). In this study, hypoxic condition also induced PI3K/Akt in PC-3 cells (Fig. 6A). Treatment with LY294002, a specific inhibitor of PI3K/Akt, supports the notion that PI3K/Akt pathway is important for hypoxia-mediated HIF-1 $\alpha$ stabilization. Consistent with its inhibitory effects on hypoxia-induced HIF-1 $\alpha$ protein accumulation and VEGF expression, HS-1793 inhibited hypoxia-stimulated activation of PI3K/Akt in a concentration-dependent manner (Fig. 6B), suggesting the involvement of this signaling pathway.

Most recently, studies have shown that HIF-1 $\alpha$ overexpression, either as a result of intratumoral hypoxia or genetic alterations, activates the transcription of genes, the protein products of which contribute to the basement membrane invasion of colon cancer cells. These findings provided a molecular basis for clinical and experimental evidence associating tumor invasion and patient mortality with hypoxia and/or HIF-1 $\alpha$ overexpression (36). In this study, HS-1793 inhibited the stimulatory effects of hypoxia on the invasive ability of PC-3 cells (Figs. 9 and 10), which could be attributed to its potent inhibitory effects on hypoxiainduced HIF-1 $\alpha$ protein accumulation and VEGF expression (Fig. 4). However, additional studies are needed to identify the associated genes that are directly or indirectly involved in HS-1793-regulated cancer cell invasion in response to hypoxia and/or HIF-1 $\alpha$ overexpression.

In conclusion, HS-1793 downregulated HIF-1 $\alpha$ protein levels in PC-3 cells. This inhibition of HIF-1 $\alpha$ protein expression was associated with destabilization of HIF-1 $\alpha$ protein, prevention of HIF- $1 \alpha$ target gene activation. HS-1793 also inhibited hypoxia-induced cell migration. These data suggested that HS-1793 may inhibit human prostate cancer progression and angiogenesis by inhibiting HIF-1 $\alpha$ and VEGF expression. Moreover, HS-1793 showed more potent effect than resveratrol on the cytotoxicity of PC-3 cells. Taken together, these results implied that HS-1793 might be a new potent chemopreventive agent against human prostate cancer cells.

\section{Acknowledgements}

This research was supported by Basic Science Research Program through the National Research Foundation of Korea (NRF) funded by the Ministry of Education, Science and Technology (2012R1A1A2006753).

\section{References}

1. Semenza GL: Hypoxia and cancer. Cancer Metastasis Rev 26: 223-224, 2007.

2. Harris AL: Hypoxia - a key regulatory factor in tumour growth. Nat Rev Cancer 2: 38-47, 2002.

3. Semenza GL: Regulation of cancer cell metabolism by hypoxia-inducible factor 1 . Semin Cancer Biol 19: 12-16, 2009.
4. Baek JH, Jang JE, Kang CM, Chung HY, Kim ND and Kim KW: Hypoxia-induced VEGF enhances tumor survivability via suppression of serum deprivation-induced apoptosis. Oncogene 19: 4621-4631, 2000.

5. Semenza GL: Hypoxia-inducible factors: mediators of cancer progression and targets for cancer therapy. Trends Pharmacol Sci 33: 207-214, 2012.

6. Al-Ubaidi FL, Schultz N, Egevad L, Granfors T and Helleday T: Castration therapy of prostate cancer results in downregulation of HIF-1alpha levels. Int J Radiat Oncol Biol Phys 82: 1243-1248, 2012.

7. Marignol L, Rivera-Figueroa K, Lynch T and Hollywood D: Hypoxia, notch signalling, and prostate cancer. Nat Rev Urol 10: 405-413, 2013

8. Szliszka E, Czuba ZP, Domino M, Mazur B, Zydowicz G and Krol W: Ethanolic extract of propolis (EEP) enhances the apoptosis-inducing potential of TRAIL in cancer cells. Molecules 14: 738-754, 2009.

9. Syed DN, Suh Y, Afaq F and Mukhtar H: Dietary agents for chemoprevention of prostate cancer. Cancer Lett 265: 167-176, 2008.

10. Santos JA, de Carvaho GS, Oliveira V, Raposo NR and da Silva AD: Resveratrol and analogues: a review of antioxidant activity and applications to human health. Recent Pat Food Nutr Agric 5: 144-153, 2013.

11. Benitez DA, Pozo-Guisado E, Alvarez-Barrientos A, Fernandez-Salguero PM and Castellon EA: Mechanisms involved in resveratrol-induced apoptosis and cell cycle arrest in prostate cancer-derived cell lines. J Androl 28: 282-293, 2007.

12. Cao Z, Fang J, Xia C, Shi X and Jiang BH: trans-3,4,5'Trihydroxystibene inhibits hypoxia-inducible factor 1alpha and vascular endothelial growth factor expression in human ovarian cancer cells. Clin Cancer Res 10: 5253-5263, 2004.

13. Zhang Q, Tang X, Lu QY, Zhang ZF, Brown J and Le AD: Resveratrol inhibits hypoxia-induced accumulation of hypoxiainducible factor-1alpha and VEGF expression in human tongue squamous cell carcinoma and hepatoma cells. Mol Cancer Ther 4: 1465-1474, 2005.

14. Park SY, Jeong KJ, Lee J, et al: Hypoxia enhances LPA-induced HIF-1alpha and VEGF expression: their inhibition by resveratrol. Cancer Lett 258: 63-69, 2007.

15. Jeong SH, Lee JS, Jeong NY, et al: A novel resveratrol analogue HS-1793 treatment overcomes the resistance conferred by Bcl-2 and is associated with the formation of mature PML nuclear bodies in renal clear cell carcinoma Caki-1 cells. Int J Oncol 35: 1353-1360, 2009.

16. Ha YM, Chung SW, Song S, Lee H, Suh H and Chung HY: 4-(6-Hydroxy-2-naphthyl)-1,3-bezendiol: a potent, new tyrosinase inhibitor. Biol Pharm Bull 30: 1711-1715, 2007.

17. Jeong SH, Hanh TM, Kim HK, et al: HS-1793, a recently developed resveratrol analogue protects rat heart against hypoxia/reoxygenation injury via attenuating mitochondrial damage. Bioorg Med Chem Lett 23: 4225-4229, 2013.

18. Um HJ, Bae JH, Park JW, et al: Differential effects of resveratrol and novel resveratrol derivative, HS-1793, on endoplasmic reticulum stress-mediated apoptosis and Akt inactivation. Int J Oncol 36: 1007-1013, 2010.

19. Jeong SH, Song IS, Kim HK, et al: An analogue of resveratrol HS-1793 exhibits anticancer activity against MCF-7 cells via inhibition of mitochondrial biogenesis gene expression. Mol Cells 34: 357-365, 2012

20. Kim HJ, Yang KM,Park YS, et al: The novel resveratrol analogue HS-1793 induces apoptosis via the mitochondrial pathway in murine breast cancer cells. Int J Oncol 41: 1628-1634, 2012.

21. Jeong SH, Jo WS, Song S, et al: A novel resveratrol derivative, HS1793, overcomes the resistance conferred by Bcl-2 in human leukemic U937 cells. Biochem Pharmacol 77: 13371347, 2009.

22. Jeong MH, Yang KM, Choi YJ, et al: Resveratrol analog, HS-1793 enhance anti-tumor immunity by reducing the $\mathrm{CD} 4{ }^{+} \mathrm{CD} 25^{+}$regulatory $\mathrm{T}$ cells in FM3A tumor bearing mice. Int Immunopharmacol 14: 328-333, 2012.

23. Choi YJ, Yang KM, Kim SD, et al: Resveratrol analogue HS-1793 induces the modulation of tumor-derived T cells. Exp Ther Med 3: 592-598, 2012.

24. Jeong NY, Yoon YG, Rho JH, et al: The novel resveratrol analog HS-1793-induced polyploid LNCaP prostate cancer cells are vulnerable to downregulation of Bcl-xL. Int J Oncol 38: 1597-1604, 2011. 
25. Semenza GL: Hypoxia, clonal selection, and the role of HIF-1 in tumor progression. Crit Rev Biochem Mol Biol 35: 71-103, 2000.

26. Semenza G: Signal transduction to hypoxia-inducible factor 1 . Biochem Pharmacol 64: 993-998, 2002.

27. Wu H, Liang X, Fang Y, Qin X, Zhang Y and Liu J: Resveratrol inhibits hypoxia-induced metastasis potential enhancement by restricting hypoxia-induced factor- 1 alpha expression in colon carcinoma cells. Biomed Pharmacother 62: 613-621, 2008.

28. Copple BL, Bustamante JJ, Welch TP, Kim ND and Moon JO: Hypoxia-inducible factor-dependent production of profibrotic mediators by hypoxic hepatocytes. Liver Int 29: 1010-1021, 2009.

29. Yasuda H: Solid tumor physiology and hypoxia-induced chemo/radio-resistance: novel strategy for cancer therapy: nitric oxide donor as a therapeutic enhancer. Nitric Oxide 19: 205-216, 2008.

30. Thorpe JF, Jain S, Marczylo TH, Gescher AJ, Steward WP and Mellon JK: A review of phase III clinical trials of prostate cancer chemoprevention. Ann R Coll Surg Engl 89: 207-211, 2007.
31. Fernandez PL, Hernandez L, Farre X, Campo E and Cardesa A: Alterations of cell cycle-regulatory genes in prostate cancer. Pathobiology 70: 1-10, 2002.

32. Antonarakis ES and Carducci MA: Targeting angiogenesis for the treatment of prostate cancer. Expert Opin Ther Targets 16: 365-376, 2012.

33. Cottart $\mathrm{CH}$, Nivet-Antoine $\mathrm{V}$ and Beaudeux JL: Review of recent data on the metabolism, biological effects, and toxicity of resveratrol in humans. Mol Nutr Food Res June 6, doi: 10.1002/ mnfr.201200589, 2013.

34. Arvelo F and Cotte C: Hypoxia in cancer malignity. Review. Invest Clin 50: 529-546, 2009 (In Spanish).

35. Mirzoeva S, Kim ND, Chiu K, Franzen CA, Bergan RC and Pelling JC: Inhibition of HIF-1 alpha and VEGF expression by the chemopreventive bioflavonoid apigenin is accompanied by Akt inhibition in human prostate carcinoma PC3-M cells. Mol Carcinog 47: 686-700, 2008.

36. Krishnamachary B, Berg-Dixon S, Kelly B, et al: Regulation of colon carcinoma cell invasion by hypoxia-inducible factor 1 . Cancer Res 63: 1138-1143, 2003. 